\title{
Chrysostom on hunger and famine
}

Author:
Hennie Stander ${ }^{1}$
Affiliation:
'Department of Ancient
Languages, University of
Pretoria, South Africa
Correspondence to:
Hennie Stander
email:
hennie.stander@up.ac.za
Postal address:
Department of Ancient
Languages, University of
Pretoria, Lynwood Road,
Hatfield 0083, Pretoria,
South Africa
Dates:
Received: 01 June 2010
Accepted: 13 Sept. 2010
Published: 07 June 2011
How to cite this article:
Stander, H., 2011,
'Chrysostom on hunger and
famine', HTS Teologiese
Studies/Theological Studies
$67(1)$, Art. \#880, 7 pages.
DOI: $10.4102 /$ hts.v67i1.880

(C) 2011. The Authors. Licensee: OpenJournals Publishing. This work is licensed under the Creative Commons Attribution License.
This article looked at hunger and famine in Chrysostom's time. It has always been tragic and ironic that hunger should exist in a world of plenty. This topic has been discussed from an economic, social, theological, philosophical, medical, humanitarian and exegetical perspective. Chrysostom's statements on this issue are studied, but our concern is only involuntary hunger, whilst voluntary forms of self-denial are being excluded. An attempt is made to define a social construct of poverty and hunger in Chrysostom's world.

\section{Introduction}

It is a great privilege for me to contribute to a Festschrift that is dedicated to Andries Van Aarde, a treasured colleague of mine. In his well-known book Fatherless in Galilee, Andries portrays Jesus as fatherless and thus marginalised and he shows how his fatherlessness was foundational in his ministries to outcasts in the society. In this article, I want to focus on another marginalised group of people, namely the hungry and poor people of the 4th century.

Food shortages, famines and plagues were endemic in the ancient world (cf. Garnsey 1990:126; Holman 1999:338; Holman 2001:67). Very limited strategies existed to confront the danger of famine (Jameson 1983:7). Hunger affects not only the physical body of the starving individual, but also the interaction between the individual and the larger community (Holman 2001:64). Famines (and the fear of famines) often led to social dislocation and even to riots (cf. Winter 1989). This could have serious political consequences. However, famine in the ancient world was always essentially attributed to one's positioning in terms of social class since poor people did not have the same resources as rich people (Gapp 1935; Millman \& Kates 1990:12). The rich often managed to escape the experience of hunger in times of famine, whilst the poor were the first to become poorer and hungry. Hunger and famine are therefore important phenomena that need to be studied in our attempts to understand the ancient world.

Garnsey (1990), who has done extensive research on famine in the ancient world, focussed largely on Athens and Rome in his work. There are therefore areas that have not yet been studied properly; Holman (2001:68), for example, says that Garnsey does not discuss Asia Minor in detail. This article will focus on what Chrysostom said about famine and hunger in Antioch and Constantinople, two powerful cities of the late antique Mediterranean world (Mayer 2006:465). Antioch was a commercial centre and its port linked the trade routes from the East with the Mediterranean (Mango 1991:114). The population in Constantinople rose sharply in the 4th-5th century as can be seen in their expanded harbour capacity, granaries and water supply during this period (Mango 1991:508). Unfortunately one does not always know whether Chrysostom's extant sermons were preached by him as a presbyter at Antioch or as bishop at Constantinople (Finn 2008:150; cf. also Mayer 2009:70-71).

Poverty can take on various forms: It can refer to those who are without land, or without wealth, or without status and power. In this article we will look at one aspect of poverty only, namely to be without food. Food is amongst the most basic of human needs (Millman \& Kates 1990:3). Although Holman (2006:443) warns us to be aware of the fact that ancient writers can have a rhetorical or moral agenda, she still believes that we can use ancient writings to ask what the daily life experiences of the poor were in the ancient world. The aim of this article will be to construct an image of hunger and famine in the 4th century by reviewing Chrysostom's sermons. This will help us to glean insight into the social problems in Chrysostom's time and to see how this aspect of poverty was interpreted from various points of view.

\section{An economic perspective}

Chrysostom gives us a graphic description of what happens when there is an economic crises and when a whole community suffers because of drought and famine (De sancto hieromartyre Babyla, MPG 50.531A). He paints a picture wherein the market place is empty of wares and the workshops are full of confusion. Everyone is eager to snatch up whatever comes first into the 
market. Even nature suffers and on the fields, the afflictions of sheep caused by famine are manifest (De sacerdotio, SC 272 ii.2.16-23); drought, on the other hand, ruined the ears of corn (Quod nemo lauditur, nisi, SC 103 ii, 11-14).

Drought and wars are some of the most common causes of hunger. Since hunger is one of the most basic needs of a human being, nothing is more painful than hunger ( $\mathrm{Ad}$ populum Antiochenum, hom v, MPG 49.72B). People in ancient communities feared hunger and famine and would even do things they would normally not do. A farmer who would normally give up when he is confronted by a piece of land which is hard to cultivate, would continue just because of his fear of impending famine (De sacerdotio, SC 272 v.8.19-27).

Communal living helped to alleviate economical hardship and to provide food to the hungry. Monasteries, for example, did much to protect people against suffering from hunger (In Acta apostolorum hom xi, MPG 60.97C-D). Chrysostom could not think of a single case where a monk died of hunger. $\mathrm{He}$ explains the underlying economic principle by referring to an ordinary family of ten children, plus their father and mother. He says it is much cheaper for them to live together and eat at one table, than to live separately. The help that came from monasteries grew in the course of time (cf. Finn 2008:114).

However, hunger is not only caused by drought and famine. Chrysostom says that rich people should also be held responsible for hunger (Ad illuminandos catecheses ii, MPG 49.237C-D). This statement is not only based in terms of economic thinking that goods are limited (cf. Pilch \& Malina 2000:122-127) or in social terms that the rich should give alms to the poor. There is another concept lying behind his charge against the rich, namely that the rich are misusing the available resources because of misplaced values and judgements. They think that gold is more valuable than iron, even though iron is more useful since it is used in countless skills and can furnish us with the greater part of our needs. Similarly, the rich do not realise that the stones used to build houses are more useful than precious stones such as pearls. Because of their wrong economic thinking, they devote all their attention to matters that do not fill our needs.

It is an economic reality that whilst there are people who cannot afford to buy bread and who waste away because of hunger, the relatively well-off people will be less likely to suffer (Millman \& Kates 1990:12). In many societies, there is a deep chasm between rich and poor. Chrysostom often highlights this economic inequality by comparing the fate of the hungry person with the life of a rich person (Leyerle 1994:29). He says that the faces of the mules that draw the rich person's wife glisten with gold in abundance, as do the skins and wood which compose that canopy. The seat and footstool are all made of gold and silver. On the other hand, the bodies of Christ, the members of the congregations, do not even have enough food (In epistulam ad Romanos hom xi, MPG 60.492A-B).
These rich people often exploited the hardships of their fellow human beings. Chrysostom tells us about a drought that once overtook his city (In epistulam $i$ ad Corinthios hom xxxix, MPG 61.343B-C). People prayed and when it seemed good to God, He sent plentiful rain. Everybody was in a festive mood, except one rich man. He said that he had ten

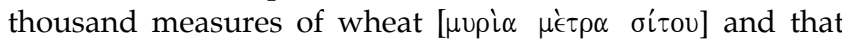
he would now no longer be able to dispose of them. Whilst hungry people were rejoicing because of the rain, this rich man grieved (cf. also Rathbone 1983:49).

A further economic reality is that people often find it almost impossible to escape a life of poverty. Many are tormented with famine and hunger all their life (In epistulam ad Romanos hom xxxi, MPG 60.674A; cf. also In paralyticum demissum per tectum, MPG 51.61B). This will be their lot for the rest of their lives, even though they labour throughout the winter, face frost and rain and are being exploited by their masters (In Matthaeum hom lxi, MPG 58.591D). It seems that it was mostly

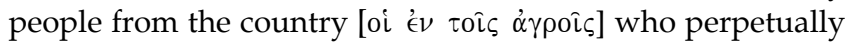
struggled with hunger (In epistulam ad Colossenses hom 1, MPG 62.306A).

Chrysostom gives us a very good indication of the economic strata that existed in his city which included:

- the upper classes constituting a select few

- the plentiful middle classes

- the lower classes.

There are therefore more than enough people who can feed the hungry people, but they do not do it because of their great

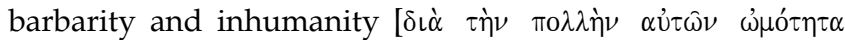
к $\alpha \dot{\alpha} \pi \alpha \nu \theta \rho \omega \pi i \alpha \nu]$, In Matthaeum hom lxvi, MPG 58.630A-B). According to his figures, only $10 \%$ of the population were poor, whilst the rest covered the range in between (Mayer 2006:467). However, as Mayer (2006:468) and Brown (2002:14) point out, Chrysostom probably minimises the level of poverty and exaggerates the level of wealth in order to show how easy it is for the rich to solve the problem of poverty.

\section{A social perspective}

Chrysostom's writings give us a vivid description of the social effects of famine and hunger in his community. Poor people have to go to bed with hunger pangs (In epistulam $i$ ad Corinthios hom xi, MPG 61.306A); beggars waste away with hunger (In Eutropium, MPG 52.393B) which often resulted in 'the most pitiable death' (Ad Theodorum lapsum, SC i.7.44-45). Hungry people wail as they pass through the streets (In Joannem hom lxxvii, MPG 59.418D) and go to the market place,

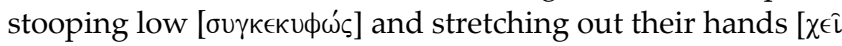
$\left.\rho \alpha \varsigma \pi \rho 0 \tau \epsilon^{\prime} \nu \omega \nu\right]$. They walk like the dogs in alleys (in darkness and in mire) and sleep on pallets of straw (In epistulam i ad Corinthios hom xi, MPG 61.94D). In the meantime, rich people sit inside their houses at their table laughing and enjoying themselves, paying no attention to the cries of the hungry (In Joannem hom lxxvii, MPG 59.418D).

According to Chrysostom, there are people who are so hungry, that they are doing everything in their power to 
get people to pity them even going as far as blinding their children to win the favour of people who do not pity them (In epistulam $i$ ad Corinthios hom xxi, MPG 61.177C). These people think it is better not to be able to see the sunshine, than to struggle with continual famine. Chrysostom gives us more examples of what people did when they realised that they got nowhere with their piteous gestures and their words

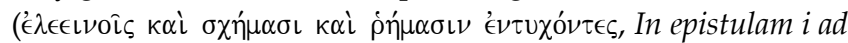
Corinthios hom xxi, MPG 61.177C-D) wherein the poor would chew the skins of worn-out shoes, or fix sharp nails into their heads, in order to draw attention. Chrysostom is convinced that these poor and hungry people surpass wonder-workers. The spectators stand laughing around them and they make a fine show of the miseries of others. The rich merely ignore the other poor and hungry people who approach them with modesty and utter disgusting comments such as 'Ought this fellow to live or at all to breathe and see this sun?' (In epistulam $i$ ad Corinthios hom xxi, MPG 61.177C-D). However, we must be aware that Chrysostom sometimes exaggerates when he describes the plight of the hungry (cf. Garnsey 1988:23).

It was customary to make rude remarks regarding beggars. People for example often called a person who asked for

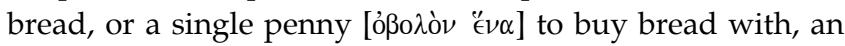

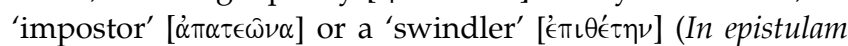
ad Hebraeos hom xi, MPG 63.96B; cf also In Acta apostolorum hom xiv, MPG 60.535D). Chrysostom argues that if such a person has asked for gold or silver or costly clothes, one could have called him a 'swindler' with good reason, but not if he or she merely asked for food. This teaches us something about the class differences and how people could shame the disadvantaged in order to advance their own standing.

The recipients showed their gratitude to the benefactors by praising and honouring them (cf. Holman 2001:32). Chrysostom says that it was expected of people who begged for bread to 'utter encomiums upon the beauty of those who pity him' (In epistulam ii ad Thessalonicenses hom xi, MPG 62.62B). This is a good example of patronage where benefactors give grace and the recipients respond with accolade. Even worse, their hunger compels them to be

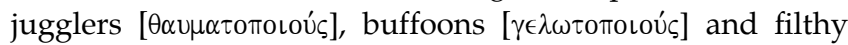

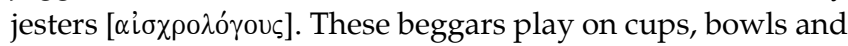
cans as cymbals and having a pipe, whistle on its base and amorous melodies and sing them at the top of their voice. Many stand round and some give them a piece of bread, some a penny and both men and women enjoy the entertainment.

Holman (2006:447) and Mayer (2006:466) warn that one should always be mindful not to regard all these descriptions of beggars as realia. It is also possible that these descriptions function as rhetorical techniques to evoke emotion in order to persuade an audience to modify their life (cf. also Allen, Neil \& Mayer 2009). On the other hand, these descriptions

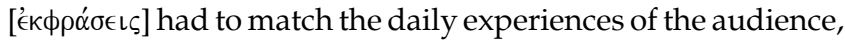
to a lesser or greater extent, in order to be effective.

Hunger and the dread of famine can indeed compel one to act shamelessly. Even widows are sometimes constrained to put off shame and to beg. Because of their shamelessness, they are then insulted and that causes them to become despondent (De sacerdotio, SC 272 iii.12.63ff). Thus the one misfortune leads to another misfortune that is even bigger and at the end one's soul is overcome by gloom and despondency.

Hunger also contributed to prostitution (Mayer 2006:471); harlots stand in front of their house and sell their bodies for money (In epistulam ad Hebraeos hom xv, MPG 63.120D). Chrysostom says that this is of course not a sufficient excuse, because they could have gained a livelihood by work. Prostitutes did have better alternatives to alleviate their hunger, whilst prisoners had no choice at all. It was apparently common practice to ill-treat prisoners and they often suffered from hunger (In Joannem hom lx, MPG 59.333B; In epistulam i ad Corinthios hom ix, MPG 61.77A). Chrysostom says that when one entered a prison, one would see some prisoners who were bound, others were covered with filth, others with uncut hair and clothed in rags, others perishing with hunger and running like dogs to your feet, others with deep ploughed sides. The prison-keepers even took the prisoners in chains to the market place where they had to beg all day; when evening comes, their keepers demanded a significant portion of the beggars' takings.

\section{A theological perspective}

Chrysostom often refers to the fact that both Jesus and the disciples struggled with continual hunger, but they controlled themselves and made no account of the things of the body (In Matthaeum hom. xxxix, MPG 57.434C). The apostles, too, struggled continually with hunger, thirst and nakedness but these sufferings caused them to be illustrious and distinguished (Quod nemo lauditur, nisi, SC 103 iv.11-14). Paul is also often used as an example of someone who had to suffer numerous hardships such as beatings and scourgings, hatred, shipwrecks, attacks of robbers, plots of his own kinsfolk and, of course, hunger (Ad Theodorum lapsum, SC 117 i.15.20-28).

Since classical times, famine was linked to a fatalistic view of the world (Jameson 1983:7). Chrysostom makes it clear that famines, pestilences and wars are the result of God's wrath (In epistulam ad Romanos hom iii, MPG 60.411D). God sustains day by day those who live according to his instructions and therefore He will never hand them over to hunger (In Acta apostolorum hom ix, MPG 60.84D). But God punishes sins. Chrysostom refers for example to Josephus' account of the famine that struck Judea (In Matthaeum hom lxxvi, MPG 58.695B). It was so severe that mothers fought about devouring their children and that the people ripped open the bellies of the dead to find some food. Chrysostom is sure that this happened because of God's wrath because they had rejected Christ (Basil also ascribed environmental disaster to avarice and ingratitude to God [Holman 2001:78]).

Elsewhere, Chrysostom refrains from saying that God causes hardships, but he merely argues that God permits $[\alpha \phi \hat{\eta}$

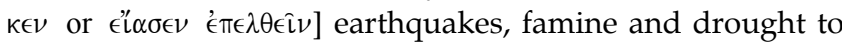


happen (Ad populum Antiochenum hom iii, MPG 49.57D; In Matthaeum hom lxxv, MPG 58.687C). God therefore could have prevented what took place. However, there were also other theological points of view in Chrysostom's times. He complains that there are other people who deceive [ $\alpha \pi \alpha \tau \omega \hat{\nu} \nu \tau \epsilon \varsigma]$

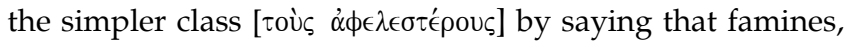
droughts and wars are unworthy of the providence of God (Ad populum Antiochenum hom vii, MPG 49.94B). There were

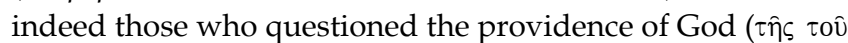

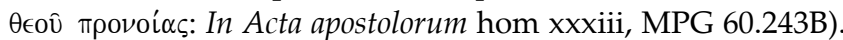
Chrysostom's answer is that when God brings upon us a famine, or a war, or any calamity whatsoever, He does it with

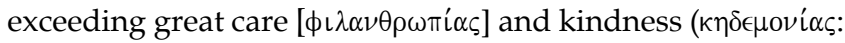
Ad populum Antiochenum hom vii, MPG 49.94B). Excellent fathers who love their children, will inflict stripes and punish their children in endless other ways of this kind to correct them when they are disorderly.

Chrysostom's theology regarding calamities led to another question: Why is God chastening poor people only, seeing as only poor people suffer from hunger? (De diabolo tentatore i.5, MPG 49.252A). On this question, Chrysostom answers that God chastens rich people with countless other things, such as dangers, diseases and untimely deaths. He then adds that God is full of resources and that He has many different medicines in order to bring about our salvation. Chrysostom also uses a forensic image to explain what he means (De diabolo tentatore i.5, MPG 49.252B). He says that a judge uses an executioner to execute the judgement. Similarly, God uses famine to correct us and lead us away from vice. No hungry person should ever think that God hates him or has abandoned him (In paralyticum demissum per tectum, MPG 51.61B). Although God uses hardships to correct our way of living, the effects are unfortunately not lasting (Ad populum Antiochenum hom iii, MPG 49.57D). After a while, we return to our former course.

The good news is that God can change poverty and famine or anything else whatsoever that has come upon us (In epistulam ad Romanos hom xv, MPG 60.540D). This is proof of his unspeakable power. He can make things that are seemingly

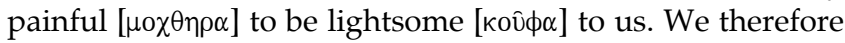
should never be distressed or despondent when famines, drought, immoderate rains [' $\epsilon$ mо $\mu \beta \rho i \alpha \varsigma]$ and irregularities in the atmosphere [ $\dot{\alpha} \epsilon \rho \omega \nu \dot{\alpha} \nu \omega \mu \alpha \lambda \dot{i} \alpha \varsigma]$ chasten the human nature (De diabolo tentatore i.4, MPG 49.250D). God is the source of these things since He even chastens the body that the soul may become sound. Chrysostom therefore argues that we should never call these events 'evil', since they are sources of good to us. These events have many benefits. They chasten our pride, goad our sloth and lead us onto zeal and make us more attentive.

Therefore, a person who is struggling with famine and who is

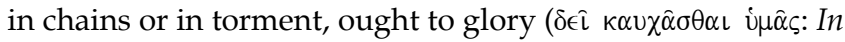
epistulam ad Romanos hom ix, MPG 60.469B-C). Chrysostom says that this may sound strange [ $\left.\xi^{\prime} \in \nu \nu \nu\right]$ and paradoxical [ $\left.\pi \alpha \rho \alpha \dot{\delta} \delta \xi_{0 \nu}\right]$, but we should remember that tribulations are in their own selves a goodly thing. It is because they anoint us unto patient abiding. Paul serves as a good example to people suffering from extreme hunger that one should never think that one is hungry because God has abandoned one (In paralyticum demissum per tectum, MPG 51.61B). Paul was especially dear to God, yet God allowed Paul also to be hungry.

Chrysostom also employed his theology regarding famine and hunger in his arguments against the Marcionites. The latter believed that the God of the Old Testament was a cruel God, whilst the God of the New Testament was much milder. Chrysostom then argues that the tribulations that Christ spoke about were far more severe than the famines that happened during Old Testament times (In Acta apostolorum hom v, MPG 60.53C). Moreover, Chrysostom emphasises that Jesus manifested his humanity by suffering from hunger and by experiencing the infirmities of human nature (In illud: Pater si possibile est, transeat iv, MPG 51.37D).

Because God was perceived as the creator of famine, one could pray and ask God to intervene. Inhabitants of a city or town often went to ascetics in the deserts to pray for a region that was suffering because of drought and famine. God then listened to the prayers of these people and put an end to the drought (Ad Theodorum lapsum, SC 117 i.19.52-55).

\section{A philosophical perspective}

Hunger and famine were not necessarily regarded as negative experiences (cf. Malherbe 1986:141-143). Joy and happiness do not depend on power, wealth, sumptuousness of the table

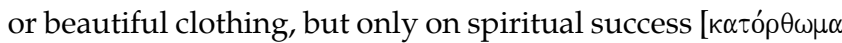

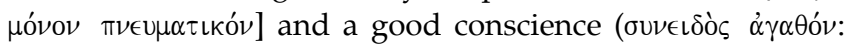
In epistulam ad Romanos hom i, MPG 60.400C-D). When your conscience is cleansed, even though you are clad in rags and struggle with famine, you are of better spirits than those that have everything. One may argue that a hungry man is inflicted by worries about food, but a rich person worries about numerous other matters (In Acta apostolorum hom li, MPG 60.357D). The rich man is perhaps not afraid of hunger, but he often fears for other things, including his life. Moreover, hunger is always conducive to enjoyment and health (Quod nemo lauditur, nisi, SC 103 vii.54-61). Somebody who is hungry is more capable of enjoying food (Ad populum Antiochenum hom 11, MPG 49.44A). Even though the most common food is served, it will taste sweeter than any delicacy. Because wealthy people do not wait until they are hungry, they have no sensation of pleasure even when the most refined dainties are spread before them.

\section{A medical perspective}

To overeat is much more harmful to the body than to suffer from hunger (In epistulam ad Colossenses hom i, MPG 62.306A; In epistulam ad Hebraeos hom xxix, MPG 63.208A). As an example of this, one might be able to endure hunger for up to twenty days, but one cannot endure overeating for longer than two days. Those who live in the countryside are always struggling with hunger, yet they are healthy, whilst those 
who tend to overeat, always have to call in the physicians. One should therefore never eat too much (Quod nemo lauditur, nisi, SC 103 vii.57-61). That is why Medical Science prescribed that those who suffered from certain diseases of the spleen or stomach, should subject themselves to hunger and thirst if they want to have some hope of recovery ( $A d$ populum Antiochenum hom vi, MPG 49.89C-D). But if these people prefer to enjoy food and a variety of delicacies, they worsen their disease. When one oversteps the limits, it imposes a load upon the body. One should eat only so much as to break one's hunger and wear only so much clothing as to be sheltered (In epistulam ad Romanos hom xxv, MPG 60.628B). Moderation is the key word.

Chrysostom argues that God has formed our bodies in moderate proportions so that we do not need much and that we would be able to adapt to another life (In epistulam ad Ephesios hom xix, MPG 62.129A-B). God therefore does not allow us immoderate indulgence. A little cup of wine and a single loaf are enough to satisfy a man's hunger. Alhough the human being is lord of all creation, God has formed him so that he needs less food than wild beasts.

Chrysostom often denounces gluttony (In Acta apostolorum hom xxvii, MPG 60.208D). He uses hunting dogs to prove his point (In Acta apostolorum hom xxxiv, MPG 60.250D-251A): Owners of hunting dogs always make sure that their dogs do not eat more than that is necessary so that they can be fit for hunting. But the irony is that the owners of these dogs do not themselves avoid luxury. After a dog has caught his prey, he will still not eat it, though he sees his meal ready before him and though hunger urges him on. But the dogs' owners do not have the same discipline and cannot constrain themselves.

The physicians call this lack of self-discipline in terms of over-

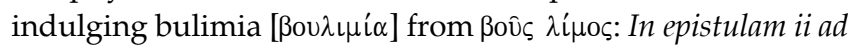
Timotheum hom vii, MPG 62.639B). It is even more lamentable when one's soul is suffering from bulimia, because avarice is also a hunger of the soul, which is always filling, but never satisfied. Those who are affected with bulimia [ßou $\lambda \iota \mu \iota \omega \nu \tau \tau \alpha \varsigma]$ are always hungry, just as drunkards are always thirsty (In epistulam ii ad Thessalonicenses hom i, MPG 62.471B).

There is something else which is worse: There are people in Chrysostom's congregation who, when they are about to fast, first of all eat excessively, 'as if the belly were on the point of being delivered over to a sort of lengthened siege' (Ad populum Antiochenum vol. 9, MPG 49.153C). The same happens again after they have fasted: they then run to the table with unseemly greediness, just as if they want to undo again the advantage gained through the fast.

\section{Exegetical perspective}

Chrysostom was often eager to highlight instances where hunger, food and famine featured in Biblical stories This is also clearly illustrated in Chrysostom's exegesis of Paul's comments on the communal meal in 1 Corinthians 11 (In epistulam $i$ ad Corinthios hom xxvii, MPG 61.223D-232D; see also Blue 1991). He would then focus on these elements in his exegesis and use them to draw important exegetical conclusions. In the account where Jesus, for example, fed 5000 people, Chrysostom points out that Christ allowed the 5000 men to hunger before He fed them. Chrysostom's explanation is that Jesus wanted to make sure that no one could later on argue that what took place was an illusion ( $\phi \alpha \nu \tau \alpha \sigma i \alpha \nu$ : In Matthaeum hom. xlix, MPG 58.499C). Jesus could have appeased their hunger only, but the disciples would then not have known his power. The people themselves did not tell Jesus that they were hungry, since they reverenced [ṇjovi

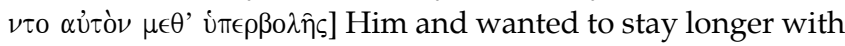
him (In Matthaeum hom. xlix, MPG 58.497B). Neither did the disciples keep the five loaves and two fish for themselves, though they too were hungry, but they were prepared to distribute their food and by doing so showed to us that they clung to spiritual food only (In Matthaeum hom. xlix, MPG 58.498D-499A).

We read in Acts 11:28 that Agabus predicted that a severe famine was about to come over all the earth. Chrysostom says that this famine struck precisely at the time when Gentiles started to join the Church (Acts 11:20-21; In Acta apostolorum hom xxv, MPG 60.193B). The pagans could therefore easily have claimed that the famine was a token of the anger of their gods because of this new religion called Christianity. However, Chrysostom could counter this argument. Firstly, Christ had already predicted that there would be tribulations. Secondly, it is clearly stated that Agabus predicted 'by the power of the Spirit' (Ac 11:28) that a famine was about to come. This famine therefore comes from God. Thirdly, this famine was caused by all the evils that had been done to the Apostles who proclaimed the message of God. But then a new question arises: Why were both groups (Jews and Gentiles) punished? For this Chrysostom has an answer ready: He says that both groups eventually benefited from this famine, since new believers very soon received the opportunity for almsgiving and therefore this famine was a means of salvation and a harbinger of many blessings (In Acta apostolorum hom xxv, MPG 60.193C).

\section{A humanitarian perspective}

Christians were often admonished by preachers to care for the hungry. Sermons provided the means to communicate moral and doctrinal messages. But we should not think that only Christians gave to the poor and the hungry. Almsgiving by pagans was just as widespread (Finn 2008:111). But whilst pagans were moved by pity, piety or philanthropy to give to the needy (cf. Finn 2008:111, 217; cf. also Konstan 2001), Christians were not persuaded by compassion only. They were reminded of the fact that hungry people represent Jesus himself (Mt 25:35 'You saw me hungered and fed me'. In Matthaeum hom. iv, MPG 57.54A; In Matthaeum hom xxvi, MPG 57.333D-334B; In Matthaeum hom 1, MPG 58.510A). Alhough the poor and the hungry were without power on earth, by being identified with Christ, they paradoxically enjoyed power in heaven (Holman 2006:461). Chrysostom 
says that Jesus did not ask us to give a costly table to the hungry (In Matthaeum lxxix, MPG 58.718B). Christ's request was actually very simple. Only bread is needed. We only have to give what is needful.

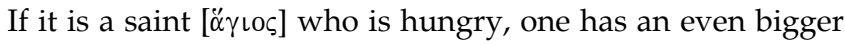
obligation to give him food (In epistulam ad Philippenses hom $\mathrm{i}$, MPG 62.188C). This is probably due to the perception that although poverty is caused by economic reasons, saints are presumed poor because of voluntary poverty and primacy should always be given to the voluntary poor (Holman 2001:4; Mayer 2009:96-104). Christ does not praise the righteous because they have not been covetous, or because they have not robbed people. These are unimportant matters. However, Christ praises the righteous because they have given food to Christ when He was hungry (In epistulam ad Philippenses hom vi, MPG 62.221D). It is not only wealthy people who should care. Chrysostom praises people who are not stingy and who are willing to distribute what they have even when they themselves are suffering from famine ( $A d$ populum Antiochenum hom xvii, MPG 49.176D).

It was for one's own benefit to give to Christ who is hunger and who is naked, since He will then feed us and He will keep us safe (In Joannem hom xxv, MPG 59.152B). Charity also had a salvatory function (Holman 2001:54), since the poor and the hungry people could help one to obtain salvation (In Joannem hom xxvii, MPG 59.162A). We give food to the hungry so that we may have confidence before God and to obtain the blessings promised through Jesus Christ (In epistulam ii ad Thessalonicenses hom vii, MPG 62.540A). But the opposite is also true: when one allows the poor man to waste away with hunger, that man will draw upon one the same condemnation (In Joannem hom xlvii, MPG 59.268C). Those who did not have compassion with hungry people and who did not share their possessions with the hungry people, would be punished not merely by the loss of blessings, but also by being sent to hell-fire (In epistulam ad Ephesios hom $\mathrm{xvi}, \mathrm{MPG} 62.112 \mathrm{C}$ ). It is clear that self-interest also played a role in social care.

\section{Conclusions}

Hunger and famine were dreaded phenomena in the ancient society. People were encouraged to give to the hungry, but it was not because of the modern teaching that the poor were fellow human beings who had a moral right to be helped. Self-interest of the benefactor also played a role and the Christian donor could gain divine honour through almsgiving (cf. Holman 2001:54). Since God's Word carried irrefutable authority, ancient theologians used it in their exhortations to almsgiving. They did not necessarily use the same Biblical texts, but Chrysostom's most favourable text was Matthew 25:35, in which ministering to the hungry was seen as ministering to Christ (Finn 2008:164, but see also Holman 2000:483; Ramsey 1982:226-227; Allen \& Morgan 2009:128).

Chrysostom not only exhorted his congregation to give, but he also reprimanded those who did not. Lizzi defined the exhortation to almsgiving, together with the castigation of failure to give alms, as a leitmotif of pastoral preaching in the 4 th and 5th centuries (cf. Finn 2008:173). It is also interesting to note that the hungry and the poor are not directly addressed in these sermons. It appears that these people were not in the church and that they were only objects of pity (Cunningham \& Allen 1998:14). They were ridiculed and called names serving as an indication of how low their status was in their community.

The hungry are recipients and lacked power. But we should also bear in mind that Chrysostom's descriptions are often slanted and manipulated to suit a specific situation. Chrysostom held a fatalistic view and he believed that God causes hunger and famine to improve the spiritual life of people. The hungry are identified with Christ and the rich should alleviate the lot of the hungry for their own sake. Excessiveness is harmful to the body and the soul. Hunger and famine were very prominent in the minds of the ancients and played an important role in Chrysostom's exegesis.

Hunger and famine (and its antithesis abundance and wealth) are useful in unlocking the construct of ancient society.

\section{References}

Allen, P. \& Morgan, E., 2009, 'Augustine on poverty', in P. Allen, B. Neil \& W. Mayer (eds.), Preaching poverty in Late Antiquity: Perceptions and reality, pp. 119-170, (eds.), Preaching poverty in Late Antigu
Evangelische Verlagsanstalt, Leipzig.

Allen, P., Neil, B. \& Mayer, W., 2009, 'Reading the texts: A methodology of approach to genre', in P. Allen, B. Neil \& W. Mayer (eds.), Preaching poverty in Late Antiquity: Perceptions and reality, pp. 36-68, Evangelische Verlagsanstalt, Leipzig.

Blue, B.B., 1991, 'The house church at Corinth and the Lord's Supper: Famine, food supply, and the present distress', Criswell Theological Review 5 (2), 221-239.

Brown, P., 2002, Poverty and leadership in the Later Roman Empire, University Press of New England, Hanover, NH.

Brueggemann, W., 1977, 'A Biblical perspective on the problem of hunger', The Christian Century 94, 1136-1141.

Cunningham, M.B. \& Allen, P., 1998, Preacher and audience: Studies in early Christian and Byzantine homilies, Brill, Leiden.

Finn, R., 2008, Almsgiving in the Later Roman Empire: Christian promotion and practice (313-450), Oxford University Press, Oxford.

Gapp, K.S., 1935, 'The universal famine under Claudius', Harvard Theological Review $28,258-265$.

Garnsey, P., 1983, 'Famine in Rome', in P. Gernsey \& C.R. Whittaker (eds.), Trade and famine in Classical Antiquity, pp. 56-65, Cambridge University Press, Cambridge, UK.

Garnsey, P., 1988, Famine and food supply in the Graeco-Roman World, Cambridge University Press, Cambridge, UK. doi: $10.1017 /$ CBO9780511583827

Garnsey, P., 1990, 'Responses to Food crisis in the Ancient Mediterranean World', in L.F. Newman (ed.), Hunger in History: Food shortage, poverty and deprivation, pp. 126-146, Basil Blackwell, Cambridge, MA.

Holman, S.R., 1999, 'The hungry body: Famine, poverty, and identity in Basil's Hom. 8', Journal of Early Christian Studies 7(3), 337-363. doi: 10.1353/earl.1999.0060

Holman S.R., 2000, 'The entitled poor: Human rights language in the Cappadocians', Pro Ecclesia 9, 476-489.

Holman, S.R., 2001, The Hungry are dying: Beggars and bishops in Roman Cappadocia Oxford University Press, New York. doi: 10.1093/0195139127.001.0001

Holman, S.R., 2006, 'Constructed and consumed: The everyday life of the poor in $4^{\text {th }}$ C. Cappadocia', in W. Bowden, A. Gutterdige \& C. Machado (eds.), Social and political life in Late Antiquity, pp. 441-464, Brill, Leiden.

Jameson, M., 1983, 'Famine in the Greek World', in P. Garnsey \& C.R. Whittaker (eds.) Trade and famine in Classical Antiquity, pp. 6-16, Cambridge University Press, Cambridge, UK

Kates, R.W. \& Millman, S., 1990, 'On ending hunger: The lessons of history', in L.F. Newman (ed.), Hunger in History: Food shortage, poverty and deprivation, pp. 389-407, Basil Blackwell, Cambridge, MA.

Konstan, D., 2001, Pity Transformed, Duckworth, London.

Leyerle, B., 1994, 'John Chrysostom on Almsgiving and the use of money', Harvard Theological Review 87(1), 29-47. 
Malherbe, A.J., 1986, Moral Exhortation, A Greco-Roman Sourcebook, Westminster Press, Philadelphia.

Mango, C., 1991, 'Constantinople', in A.P. Kazhdan (ed.), The Oxford Dictionary of Byzantium, pp. 508-512, Oxford University Press, Oxford.

Mango, M.M., 1991, 'Antioch', in A.P. Kazhdan (ed.), The Oxford Dictionary of Byzantium, pp. 113-116, Oxford University Press, Oxford.

Mayer, W., 2006, 'Poverty and society in the world of John Chrysostom', in L. Lavan, W. Bowden, A. Gutteridge \& C. Machado (eds.), Social and Political Archaeology in Late Antiquity, pp. 465-484, Late Antique Archaeology 3, Brill, Leiden.

Mayer, W., 2009, 'John Chrysostom on poverty', in P. Allen, B. Neil \& W. Mayer (eds.), Preaching poverty in Late Antiquity: Perceptions and reality, pp. 69-118, Evangelische Verlagsanstalt, Leipzig.

Millman, S.W. \& Kates, R.W., 1990, 'Toward understanding hunger', in L.F. Newman (ed.), Hunger in History: Food shortage, poverty and deprivation, pp. 3-24, Basil Blackwell, Cambridge, MA.
Neil, B., 2009, 'Leon I on poverty', in P. Allen, B. Neil \& W. Mayer (eds.), Preaching poverty in Late Antiquity: Perceptions and reality, pp. 171-228, Evangelische Verlagsanstalt, Leipzig.

Pilch, J.J. \& Malina B.J., 2000, Handbook of Biblical Social Values, Hendrickson Publishers, Peabody.

Ramsey, B., 1982, 'Almsgiving in the Latin Church: The Late Fourth and early Fifth Centuries', Theological Studies 43, 226-259.

Rathbone, D., 1983, 'The grain trade and grain shortages in the Hellenistic East', in P. Garnsey \& C.R. Whittaker (eds.), Trade and famine in Classical Antiquity, pp. 45-55, Cambridge University Press, Cambridge, UK.

Van Aarde, A.G., 2001, Fatherless in Galilee: Jesus as child of God, Trinity Press International, Harrisburg.

Winter, B.W., 1989, 'Secular and Christian responses to Corinthian famines', Tyndale Bulletin 40, 86-106. 